\title{
PENGGUNAAN ALGA SIAPA-AKU PADA MATERI KERAGAMAN BENTUK MUKA BUMI UNTUK MENINGKATKAN AKTIVITAS DAN HASIL BELAJAR SISWA KELAS VIIB SMP NEGERI 2 MERBAU MATARAM
}

\author{
Rahayu Dwi Mastuti Widayati \\ rahayuwidayati25@yahoo.co.id \\ Guru IPS SMP Negeri 2 Merbau Mataram
}

\begin{abstract}
ABSTRAK
Tujuan penelitian adalah untuk mengetahui peningkatan aktivitas dan hasil belajar siswa kelas VIIB SMP Negeri 2 Merbau Mataram pada materi keragaman bentuk muka bumi melalui alat peraga Siapa Aku. Metode yang digunakan mengacu model dari Hopkins yaitu dimulai dari merasakan adanya masalah, menyusun perencanaan, melaksanakan tindakan, melakukan observasi dan refleksi, kemudian melakukan rencana ulang, melaksanakan tindakan, observasi dan refleksi demikian seterusnya. Instrumen pengumpulan data melalui observasi dan tes. Data yang diperoleh berupa data kualitatif dan kuantitatif dianalisis dengan menggunakan analisis deskriptif komparatif. Variabel penelitian adalah aktivitas dan hasil belajar. Hasil penelitian menunjukkan bahwa digunakannya alat peraga Siapa-Aku pada materi keragaman bentuk muka bumi dapat meningkatkan aktivitas dan hasil belajar siswa kelas VIIB SMP Negeri 2 Merbau Mataram Tahun 2015. Pada kondisi prasiklus ketuntasan aktivitas belajar siswa adalah $25 \%$ (Belum tuntas), pada siklus I adalah $\mathbf{6 9 , 4 4 \%}$ (Tuntas) dan pada siklus II adalah $\mathbf{8 6 , 1 1 \%}$ (Tuntas). Peningkatan aktivitas belajar pada siklus I sebesar 44,44\%, siklus I ke siklus II sebesar $\mathbf{1 6 , 6 7 \%}$, sehingga total peningkatan mencapai $\mathbf{6 1 , 1 1 \%}$. Untuk ketuntasan hasil belajar siswa kelas VIIB pada kondisi prasiklus adalah 5,56\% (Secara klasikal belum tuntas), Siklus I 27,78\%(Secara klasikal belum tuntas) dan siklus II $\mathbf{8 6 , 1 1 \%}$ (Secara kalsikal sudah tuntas). Peningkatan dari prasiklus ke siklus I sebesar 22,22\%, dari siklus I ke siklus II sebesar $\mathbf{5 8 , 3 3 \%}$, Secara keseluruhan peningkatan ketuntasan hasil belajar siswa mencapai 80,55\%. Simpulan dalam penelitian adalah aktivitas dan hasil belajar siswa kelas VIIB pada materi keragaman bentuk muka bumi mengalami peningkatan setelah menggunakan alat peraga Siapa-Aku.
\end{abstract}

Kata kunci: alat peraga, aktivitas belajar, hasil belajar

\section{PENDAHULUAN}

Salah satu permasalahan yang dihadapi oleh guru mata pelajaran IPS di SMP Negeri 2 Merbau Mataram adalah rendahnya kualitas proses dan hasil belajar siswa dengan ditandai oleh rendahnya pencapaian nilai yang belum memenuhi standar kriteria ketuntasan minimum (KKM) yang telah ditetapkan. Berkualitas dan tidaknya proses pembelajaran bergantung pada kemampuan dan perilaku guru dalam pengelolaan pembelajaran. Guru harus memahami apa yang diajarkan (what to teach) dan cara mengajarnya (how to teach). Kegiatan pembelajaran IPS di SMP Negeri 2 Merbau Mataram masih bersifat teacher centered, pemanfaatan media atau alat peraga kurang sehingga suasana pembelajaran kurang menarik, membosankan dan siswa cenderung pasif karena guru kurang melibatkan siswa secara aktif dalam pembelajaran. Berdasarkan hasil tes 
pada siswa kelas VIIB materi relief daratan dan dasar laut serta tektonisme, menunjukkan nilai rata-rata 50,42, terdapat 2 siswa atau 5,56\% telah mencapai nilai KKM dan 34 siswa atau 94,44\% memiliki nilai di bawah KKM. Nilai KKM mata pelajaran IPS di SMP Negeri 2 Merbau Mataram adalah 75. Berdasarkan permasalahan di atas, agar dapat meningkatkan aktivitas dan hasil belajar siswa, peneliti menggunakan alat peraga SIAPA-AKU dalam mempelajari materi keragaman bentuk muka bumi pada siswa kelas VIIB SMP Negeri 2 Merbau Mataram Semester Ganjil Tahun 2015/2016.

\section{KAJIAN PUSTAKA}

\section{Alat Peraga}

Alat peraga dalam mengajar memegang peranan penting sebagai alat bantu untuk menciptakan proses belajar mengajar yang efektif. Dalam proses belajar mengajar alat peraga dipergunakan dengan tujuan membantu guru agar proses belajar siswa lebih efektif dan efisien (Sudjana, 2002: 59). Nana Sudjana (2002: 100-102) membedakan alat peraga menjadi dua jenis yaitu: alat peraga dua dan tiga dimensi dan alat peraga yang diproyeksi.

\section{1) Alat peraga dua dan tiga dimensi}

Alat peraga dua dimensi artinya alat yang mempunyai ukuran panjang dan lebar, sedangkan alat peraga tiga dimensi di samping mempunyai ukuran panjang dan lebar juga mempunyai ukuran tinggi. Alat peraga dua dan tiga dimensi ini antara lain bagan, grafik, poster, gambar mati, peta datar, peta timbul, globe dan lain-lain.

\section{2) Alat-alat peraga yang diproyeksi}

Alat peraga yang diproyeksi adalah alat peraga yang menggunakan proyektor sehingga gambar tampak pada layar (fil, Slide dan filmstrip)

Berdasarkan kajian pustaka di atas, alat peraga yang digunakan dalam penelitian ini adalah jenis alat peraga dua dimensi, yaitu berupa Kartu SIAPA dan Kartu AKU. Kartu SIAPA berisi pertanyaan dan Kartu AKU berisi jawaban.

\section{Aktivitas Belajar}

Aktivitas merupakan prinsip atau asas yang sangat penting di dalam proses belajarmengajar. Menurut Sardiman (2005:96) aktivitas belajar adalah serangkaian kegiatan fisik atau jasmani maupun mental atau rohani yang saling berkaitan sehingga tercipta belajar yang optimal. Keaktifan siswa dalam proses pembelajaran akan menyebabkan interaksi yang tinggi antara guru dengan siswa ataupun dengan siswa itu sendiri. Hal ini akan mengakibatkan suasana kelas menjadi segar dan kondusif, dimana masing-masing siswa dapat melibatkan kemampuannya semaksimal mungkin. Aktivitas yang timbul dari siswa mengakibatkan terbentuknya pengetahuan dan keterampilan yang mengarah pada peningkatan prestasi. Adapun jenis-jenis aktivitas belajar digolongkan oleh Paul B. Diedrich (Ahmad Rohani, 2010: 10) adalah antara lain sebagai berikut: a) Visual activities, yang termasuk di dalamnya misalnya membaca, memperhatikan gambar, demonstrasi, percobaan, pekerjaan orang lain. b) Oral Activities, seperti menyatakan merumuskan, bertanya, memberi saran, berpendapat, diskusi, interupsi. c) Listening Activities, sebagai contoh mendengarkan: uraian, percakapan, diskusi, musik, pidato. d) Writing Activities, seperti misalnya menulis cerita, karangan, laporan, menyalin. e) Drawing Activities, menggambar, membuat grafik, peta, diagram. Motor Activities, yang 
termasuk di dalamnya antara lain: melakukan percobaan, membuat konstruksi, model, mereparasi, berkebun, beternak. g) Mental Activities, sebagai contoh misalnya: menang-gapi, mengingat, memecahkan soal, meng-analisis, mengambil keputusan. $h$ ) Emotional Activities, seperti misalnya, merasa bosan, gugup, melamun, berani, tenang.

Berdasarkan uraian di atas, peneliti mengembangkan aktivitas belajar siswa dalam beberapa indikator yang akan diamati dalam penelitian ini yaitu aktif membaca atau mempelajari materi, aktif dalam kelompok, berani bertanya dan berani menjawab.

\section{Hasil Belajar}

Istilah hasil belajar dapat diartikan sebagai suatu kemampuan yang telah dimiliki seseorang yang diperoleh dari proses belajar (W.S. Winkel, 1987:38). Menurut Nana Sudjana (2004: 111) hasil belajar adalah bentuk tingkah laku yang dimiliki siswa setelah menyelesaikan pengalaman belajar. Menurut Dick \& Reiser (Djamarah Sopah, 2000:30), hasil belajar adalah kemampuan yang dimiliki siswa sebagai hasil kegiatan pembelajaran meliputi pengetahuan, keterampilan intelektual, keterampilan motorik dan sikap. Hasil belajar biasanya diperoleh setelah siswa dinyatakan berhasil dalam suatu penilaian yang dilakukan pada akhir pembelajaran. Hasil belajar yang diukur dalam penelitian ini adalah hasil belajar ranah pengetahuan. Penilaian terhadap hasil belajar dalam ranah pengetahuan menggunakan alat ukur berupa tes. Tes merupakan alat ukur yang diberikan kepada individu untuk mendapatkan jawaban-jawaban yang diharapkan, baik secara tertulis maupun secara lisan.

\section{METODE PENELITIAN}

Penelitian Tindakan Kelas ini dilaksanakan pada semester ganjil Tahun Pelajaran 2015/2016, yaitu pada Bulan Agustus sampai dengan Bulan Oktober 2015 (selama 3 bulan). Penelitian dilaksanakan di SMP Negeri 2 Merbau Mataram Jalan Pejuang Angkatan 45 Desa Merbau Mataram Kecamatan Merbau Mataram Kabupaten Lampung Selatan Propinsi Lampung.

Subyek penelitian adalah siswa kelas VIIB SMP Negeri 2 Merbau Mataram berjumlah 36 orang, terdiri dari 14 siswa laki-laki dan 22 siswa perempuan. Model Penelitian Tindakan Kelas ini mengacu model dari Hopkins dalam Wina Sanjaya (2009:53), yaitu dilakukan membentuk spiral dimulai dari merasakan adanya masalah (identifikasi masalah), menyusun perencanaan (planning), melaksanakan tindakan (acting), melakukan observasi (observing) dan refleksi (reflecting), kemudian melakukan rencana ulang, melaksanakan tindakan, observasi dan refleksi demikian seterusnya.

Instrumen penelitian atau alat pengumpul data dilakukan dengan cara observasi dan tes. Data yang diperoleh berupa data kualitatif dan kuantitatif dianalisis dengan menggunakan analisis deskriptif komparatif. Variabel dalam penelitian ini adalah aktivitas dan hasil belajar. Pencapaian Indikator aktivitas belajar secara klasikal diukur berdasarkan skala pengukuran (rating scale) sebagai berikut: Sangat aktif 76\% - 100\%, Aktif $51 \%$ - 75\%, Cukup aktif 26\% - 50\%, Kurang Aktif 1\% - 25\%. Aktivitas individu dalam lembar observasi diukur dengan skala penilaian: aktifjika melakukan $\geq 3$ aktivitas belajar, cukup aktif jika melakukan 2 
aktivitas belajar dan kurang aktif jika melakukan $<2$ aktivitas belajar. Sedangkan ketuntasan klasikal aktivitas belajar jika 50\% siswa telah melakukan $\geq$ 2 aktivitas yang diamati.

Kriteria pencapaian hasil belajar menggunakan analisis kuantitatif dalam bentuk persentase sebagai berikut: a) Nilai $\geq$ 75 (Nilai mencapai KKM atau lebih dan siswa telah tuntas) dan b) Nilai $<75$ (Nilai belum mencapai KKM dan siswa belum tuntas). Ketuntasan belajar klasikal jika 75\% siswa telah mencapai nilai KKM atau lebih.
HASIL PENELITIAN DAN PEMBAHASAN

\section{Hasil Penelitian}

\section{Kondisi Prasiklus}

Kegiatan pembelajaran IPS di SMP Negeri 2 Merbau Mataram bersifat teacher centered, guru tidak atau kurang memanfaatkan media atau alat peraga sehingga suasana pembelajaran kurang menarik dan membosankan. Banyak siswa yang diam, ngobrol dan pasif akibat guru tidak melibatkan siswa secara aktif dalam pembelajaran.

Tabel 1 Aktivitas Belajar Siswa Kelas VIIB Pada Kondisi Awal (Prasiklus)

\begin{tabular}{clcc}
\hline No & \multicolumn{1}{c}{ Kategori } & Jumlah Siswa & Persentase \\
\hline 1 & Aktif & 5 & 13,89 \\
2 & Cukup Aktif & 4 & 11,11 \\
3 & Kurang Aktif & 27 & 75,00 \\
\hline & Jumlah & 36 & 100 \\
\hline & Ketuntasan klasikal & 9 & 25,00 \\
\hline
\end{tabular}

Tabel 2 Data Nilai Rata-rata Hasil Belajar Siswa Kelas VIIB Pada (Prasiklus)

\begin{tabular}{ccc}
\hline No & Uraian & Nilai \\
\hline 1 & Nilai terrendah & 20,00 \\
2 & Nilai tertinggi & 80,00 \\
\hline & Nilai rata-rata & 50,42 \\
\hline
\end{tabular}

Tabel 3 Data Ketuntasan Belajar Siswa Kelas VIIB Pada Kondisi Awal (Prasiklus)

\begin{tabular}{cccc}
\hline No & Nilai & Jumlah Siswa & Persentase \\
\hline 1 & $<75$ & 34 & 94,44 \\
2 & $\geq 75$ & 2 & 5,56 \\
\hline & Jumlah & 36 & 100,00 \\
\hline
\end{tabular}

Berdasarkan tabel 1, aktivitas belajar siswa kelas VIIB menunjukkan 5 orang $(13,89 \%)$ aktif, 4 orang $(11,11 \%)$ cukup aktif dan 27 orang (75\%) kurang aktif. Secara klasikal ketuntasan aktivitas belajar siswa $25 \%$ (belum tuntas). Berdasarkan tabel 2 dan 3, pencapaian nilai rata-rata hasil belajar juga rendah yaitu 50,42 . Nilai terrendah 20,00 dan tertinggi
80,00 dengan ketuntasan belajar siswa sebesar 5,56\% (belum tuntas).

\section{Siklus I}

Siklus I dilaksanakan dua kali pertemuan, yaitu tatap muka (kegiatan pembelajaran) dan tes tertulis dengan materi pokok Vulkanisme. Berikut ini adalah tahap-tahap pembelajaran pada siklus I: 
Pada 10 menit pertama guru mengkondisikan kesiapan siswa, menyampaikan cakupan materi dan tujuan yang akan dicapai, memberikan arahan tentang kegiatan yang akan dilakukan dengan alat peraga SIAPA-AKU, membagi siswa dalam kelompok 6 orang.

Pada 60 menit berikutnya, guru membagikan satu lembar materi pada masing-masing kelompok, kemudian meminta siswa untuk mempelajari materi tersebut dalam waktu 10 menit. Kemudian setiap kelompok mempresentasikan alga SIAPA-AKU di depan kelas dengan cara mengambil satu persatu pertanyaan pada Kartu Siapa dalam box dan mencari jawabannya pada Kartu AKU. Jika belum menemukan jawabannya, tidak boleh melanjutkan pada kartu berikutnya dan jika sudah ditemukan jawabannya masukkan kedua kartu di box semula. Demikian seterusnya sampai 10 pertanyaan dalam 10 box dapat diselesaikan. Selanjutnya kelompok membacakan pasangan kartu satu persatu dan kelompok lain mendengarkan atau menyimak sambil memberikan penilaian atas kebenaran jawaban tersebut. Penilaian kelompok berdasarkan kecepatan dan kebenaran jawaban. Nilai 100 jika pertanyaan diselesaikan $<2$ menit, nilai 90 jika pertanyaan diselesaikan > 2 menit namun tidak lebih dari 3 menit. Kegiatan ini berakhir setelah semua kelompok sudah melaksanakan tugasnya di depan kelas. Guru memberikan rewardl penghargaan kepada kelompok yang telah menjawab dengan cepat dan benar. Kegiatan berikutnya guru melakukan pemantapan materi, tanya jawab, penguatan dan umpan balik terhadap materi yang sudah atau yang belum dipahami siswa. Pada kegiatan inilah guru melakukan observasi keberanian bertanya jawab.

Pada 10 menit akhir pembelajaran, guru bersama siswa membuat kesimpulan tentang materi Vulkanisme, melakukan refleksi dan tes tertulis serta memberikan tindak lanjut dengan memberikan tugas di rumah untuk menuliskan semua pertanyaan dan jawaban dalam buku latihan dan mempelajarinya sebagai bahan tes tertulis pada pertemuan berikutnya.

Berdasarkan hasil penelitian pada siklus I, penggunaan alat peraga SIAPAAKU dapat meningkatkan aktivitas dan hasil belajar siswa. Untuk lebih jelasnya dapat dilihat pada tabel berikut ini.

Tabel 4. Data Aktivitas Belajar Siswa Kelas VIIB Pada Siklus I

\begin{tabular}{clcc}
\hline No & \multicolumn{1}{c}{ Kategori } & Jumlah Siswa & Persentase \\
\hline 1 & Aktif & 11 & 30,56 \\
2 & Cukup Aktif & 14 & 38,88 \\
3 & Kurang Aktif & 11 & 30,56 \\
\hline & Jumlah & 36 & 100,00 \\
\hline & Ketuntasan klasikal & 25 & 69,44 \\
\hline
\end{tabular}

Tabel 5. Data Nilai Hasil Belajar Siswa Kelas VIIB Pada Siklus I

\begin{tabular}{ccc}
\hline No & Uraian & Nilai \\
\hline 1 & Nilai terrendah & 33,00 \\
2 & Nilai tertinggi & 91,00 \\
\hline & Nilai rata-rata & 66,39 \\
\hline
\end{tabular}


Tabel 6. Data Ketuntasan Belajar Siswa Kelas VIIB Pada Siklus I

\begin{tabular}{cccc}
\hline No & Nilai & Jumlah Siswa & Persentase \\
\hline 1 & $<75$ & 26 & 72,22 \\
2 & $\geq 75$ & 10 & 27,78 \\
\hline & Jumlah & 36 & 100,00 \\
\hline
\end{tabular}

Berdasarkan tabel 4, aktivitas belajar menunjukkan 11 orang $(30,56 \%)$ aktif, 14 orang $(38,88 \%)$ cukup aktif dan 11orang $(30,56 \%)$ kurang aktif. Secara klasikal ketuntasan aktivitas belajar siswa $69,44 \%$ sudah tuntas. Berdasarkan tabel 5 dan 6 , nilai rata-rata hasil belajar siklus I adalah 66,39. Jika dilihat dari ketuntasan belajar, siswa yang memperoleh nilai di bawah KKM ada 26 orang (72,22\%) dan yang mencapai nilai KKM atau lebih ada 10 orang $(27,78 \%)$. Secara klasikal belum tuntas.

Tabel 7 Data Peningkatan Ketuntasan Aktivitas dan Hasil Belajar Siswa Kelas VIIB Pada Prasiklus dan Siklus I

\begin{tabular}{clccc}
\hline No & \multicolumn{1}{c}{ Variabel } & Prasiklus & Siklus I & Peningkatan \\
\hline 1 & Aktivitas Belajar & $25,00 \%$ & $69,44 \%$ & $44,44 \%$ \\
2 & Hasil Belajar & $5,56 \%$ & $27,78 \%$ & $22,22 \%$ \\
\hline
\end{tabular}

Berdasarkan tabel 7, ada peningkatan ketuntasan aktivitas belajar dari kondisi prasiklus ke siklus I sebesar 44,44\% dan hasil belajar sebesar 22,22\%.

\section{Refleksi Siklus I}

Pada siklus I, aktivitas belajar siswa kelas VIIB tergolong cukup aktif. Ketuntasan klasikal aktivitas belajar $69,44 \%$ siswa sudah melakukan $\geq 2$ aktivitas yang diamati. Dalam hal membaca atau mempelajari materi tidak semua siswa menunjukkan keaktifannya. Ada beberapa siswa yang tidak membaca sama sekali (mengobrol dengan temannya). Pada saat presentasi alga terdapat beberapa siswa yang lambat dalam menemukan jawaban. Hal ini disebabkan siswa kurang fokus saat membaca atau mempelajari materi ada yang diam saja dan ada juga yang sambil mengobrol. Setiap kelompok dapat menyelesaikan pertanyaan rata-rata lebih dari 2 menit. Hal ini disebabkan oleh setiap kelompok hanya memiliki satu lembar materi yang diberikan oleh guru sebagai panduan menemukan jawaban. Pada penilaian kelompok ditemukan masalah yaitu terdapat kelompok yang sudah menyelesaikan 10 pertanyaan tetapi beberapa jawaban ada yang salah. Karena terburu-buru dan kurang teliti hal ini dapat terjadi. Dalam perencanaan, penilaian untuk masalah tersebut tidak dicantumkan karena guru beranggapan bahwa pertanyaan itu dapat diselesaikan dengan benar. Pada kegiatan konfirmasi guru melakukan tanya jawab tentang materi yang belum dipahami. Pada kondisi ini siswa kurang atau tidak menunjukkan keberanian untuk bertanya ataupun menjawab pertanyaan, baik pertanyaan dari guru maupun dari siswa, mereka cenderung diam. Sebagai perbaikan dalam siklus II, peneliti merencanakan kembali kegiatan pembelajaran yaitu 1) membagikan tiga lembar materi kepada setiap kelompok, 2) mengubah strategi penggunaan alga, 3) merencanakan penilaian kembali, 4) memberikan reward melalui penambahan nilai bagi siswa yang berani bertanya dan berani menjawab. 
Pencapaian nilai rata-rata 66,39 dengan ketuntasan belajar 27,78\% secara klasikal belum tuntas. Dalam mempelajari materi IPS siswa tidak hanya dituntut untuk paham, tetapi juga harus hafal. Berdasarkan tanya jawab langsung dengan semua siswa , rendahnya nilai yang dicapai akibat materi kurang dibaca secara mendalam dan tidak dihafal. Sebagian besar siswa kelas VIIB memiliki daya berpikir dan daya ingat yang rendah. Nilai hasil belajar dilakukan melalui tes tertulis bentuk uraian. Bentuk soal uraian digunakan untuk menilai kemampuan logika dan kemampuan berpikir kritis siswa serta kemampuan kognitif tingkat atas. Bagi siswa yang memiliki kemampuan berpikir rendah dan daya ingat yang lemah sangat sulit untuk menyelesaikan soal-soal tersebut. Melihat masih rendahnya hasil belajar siswa, maka perlu adanya perbaikan 1) Penekanan kembali tentang materi yang akan dimunculkan pada saat tes tertulis, 2) pemilihan jenis tes tertulis yaitu tes obyektif (Pilihan Ganda). Tes Objektif dapat digunakan untuk mengukur proses berpikir rendah sampai dengan sedang (ingatan, pemahaman, dan penerapan).

\section{Siklus II}

Pelaksanaan PTK pada siklus II dilaksanakan dua kali pertemuan yaitu tatap muka dan tes tertulis dengan materi Pelapukan, erosi dan sedimentasi. Tahaptahap pembela-jaran pada siklus ini adalah sebagai berikut:

Pada 10 menit pertama guru mengkondisikan kesiapan siswa untuk mengikuti pembelajaran, menyampaikan cakupan materi dan tujuan yang akan dicapai, rencana pembelajaran dan memberikan arahan tentang kegiatan yang akan dilakukan dengan alat peraga SIAPA-
AKU, membagi siswa menjadi 6 kelompok (setiap kelompok 6 orang).

Pada 60 menit berikutnya, guru membagikan tiga lembar materi kepada masing-masing kelompok, kemudian meminta siswa untuk mempelajari materi tersebut dalam waktu 10 menit. Guru memberikan arahan tentang perubahan dalam aturan presentasi alga yaitu 3 orang secara bersamaan bertugas mengambil Kartu SIAPA dalam box secara acak (tidak berurutan) dan 3 orang secara bersamaan bertugas mencari jawaban pada Kartu AKU. Jika sudah ditemukan jawabannya masukkan pasangan kedua kartu di box semula. Dengan cara ini kelompok dapat menyelesaikan dengan cepat. Demikian seterusnya sampai pertanyaan dalam 10 box dapat diselesaikan. Bagi kelompok yang belum selesai dalam waktu $<3$ menit, presentasi dianggap selesai. Selanjutnya kelompok membacakan pasangan kartu satu persatu dan kelompok lain mendengarkan atau menyimak sambil memberikan penilaian atas kebenaran jawaban tersebut. Penilaian kelompok sama dengan siklus I, tetapi bagi kelompok yang kurang tepat menemukan jawabannya dilakukan dengan cara: jumlah soal benar + nilai waktu dibagi 2. Setiap soal skornya 10 maka jika benar 7 nilainya 70 dengan waktu $<2$ menit maka nilainya $(70+100): 2=85$. Kegiatan ini berakhir setelah semua kelompok sudah melaksanakan tugasnya di depan kelas. Guru memberikan reward kepada kelompok yang telah menjawab dengan cepat dan benar kemudian guru melakukan pemantapan materi melalui tanya jawab, penguatan dan umpan balik terhadap materi yang sudah atau yang belum dipahami siswa. Untuk meningkatkan aktivitas bertanya dan menjawab guru memberikan reward melalui penambahan nilai bagi 
siswa yang berani bertanya dan berani menjawab.

Pada 10 menit akhir pembelajaran, guru bersama siswa membuat kesimpulan tentang materi Vulkanisme, melakukan refleksi dan tes tertulis serta memberikan tindak lanjut dengan memberikan tugas untuk menuliskan pertanyaan dan jawaban dalam buku catatan dan mempelajari materi sebagai bahan ulangan pada pertemuan berikutnya. Kemudian siswa diberi tugas untuk mencari informasi melalui internet atau pengamatan dengan memotret bentukan muka bumi hasil pelapukan, erosi air, angin di lingkungan tempat tinggal.

Tabel 8 Data Aktivitas Belajar Siswa Kelas VIIB Pada Siklus II

\begin{tabular}{|c|c|c|c|}
\hline No & Kategori & Jumlah Siswa & Persentase \\
\hline 1 & Aktif & 25 & 69,44 \\
\hline 2 & Cukup Aktif & 6 & 16,67 \\
\hline 3 & Kurang Aktif & 5 & 13,89 \\
\hline & Jumlah & 36 & 100,00 \\
\hline & Ketuntasan klasikal & 31 & 86,11 \\
\hline
\end{tabular}

Berdasarkan tabel 8, aktivitas belajar siswa kelas VIIB mengalami peningkatan yang signifikan, siswa yang aktif ada 25 orang $(69,44 \%)$, cukup aktif ada 6 orang $(16,67 \% \%)$ dan kurang aktif ada 5 orang $(13,89 \%)$. Secara kalsikal, aktivitas belajar siswa tuntas.

Tabel 9 Data Nilai Hasil Belajar Siswa Kelas VIIB Pada Siklus II

\begin{tabular}{ccc}
\hline No & Uraian & Nilai \\
\hline 1 & Nilai terrendah & 60 \\
2 & Nilai tertinggi & 100 \\
\hline & Nilai rata-rata & 81,11 \\
\hline
\end{tabular}

Tabel 10 Data Ketuntasan Belajar Siswa Kelas VIIB Pada Siklus II

\begin{tabular}{cccc}
\hline No & Nilai & Jumlah Siswa & Persentase \\
\hline 1 & $<75$ & 5 & 13,89 \\
2 & $\geq 75$ & 31 & 86,11 \\
\hline & Jumlah & 36 & 100,00 \\
\hline
\end{tabular}

Berdasarkan tabel 9 dan 10, hasil tes menunjukkan nilai terrendah 60 dan tertinggi 100 serta nilai rata-rata kelas 81,11 . Siswa yang telah mencapai nilai KKM atau lebih ada 31 orang $(86,11 \%)$ dan yang belum mencapai KKM ada 5 orang $(19,89 \%)$. Secara klasikal sudah tuntas. Untuk mengetahui besarnya peningkatan aktivitas dan hasil belajar dari siklus I ke siklus II dapat dilihat pada tabel di bawah ini.

Tabel 11 Data Peningkatan Aktivitas dan Hasil Belajar Siswa Kelas VIIB

Pada Siklus I dan Siklus II

\begin{tabular}{clccc}
\hline No & \multicolumn{1}{c}{ Variabel } & Siklus I & Siklus II & Peningkatan \\
\hline 1 & Aktivitas Belajar & $69,44 \%$ & $86,11 \%$ & $16,67 \%$ \\
2 & Ketuntasan Hasil Belajar & $27,78 \%$ & $86,11 \%$ & $58,33 \%$ \\
\hline
\end{tabular}

Berdasarkan tabel 11, terjadi peningkatan aktivitas sebesar $16,67 \%$ dan hasil belajar sebesar 58,33\%.

\section{Refleksi Siklus II}

Aktivitas belajar siswa kelas VIIB pada siklus II mengalami peningkatan yang 
signifikan. Pemberian tiga lembar materi setiap kelompok membuat anggota kelompok ikut aktif membaca dan mempelajarinya. Mengubah cara presentasi alga SIAPA-AKU, menyebabkan hampir semua anggota kelompok menunjukkan keaktifannya. Aktivitas bertanya masih rendah meskipun sudah diberikan penambahan nilai, namun demikian sudah menunjukkan peningkatan yang cukup dari prasiklus, siklus I dan siklus II. Pada Aktivitas menjawab 63,89\% siswa cukup berani untuk menjawab baik pertanyaan dari guru maupun siswa yang lain, meskipun dari segi kualitas jawaban belum sesuai dengan yang diharapkan.
Hasil belajar pada siklus II sudah di atas target keberhasilan. Aktivitas belajar yang baik memberikan pengaruh terhadap hasil belajar siswa. Penekanan kembali materi yang akan dimunculkan pada tes tertulis mempengaruhi pencapaian nilai. Selain itu pemberian tes dalam bentuk pilihan ganda juga sangat membantu siswa dalam menyelesaikan soal-soal disbandingkan dengan soal bentuk uraian.

\section{Pembahasan}

Berdasarkan hasil penelitian pada kondisi prasiklus, siklus I dan siklus II terjadi peningkatan yang signifikan dalam aktivitas dan hasil belajar siswa kelas VIIB.

Tabel 12 Perbandingan Ketuntasan Aktivitas dan Hasil Belajar Siswa Kelas VIIB Pada Kondisi Prasiklus, Siklus I dan Siklus II

\begin{tabular}{clcccc}
\hline No & Variabel & Prasiklus & Siklus I & Siklus II & Peningkatan \\
\hline 1 & Aktivitas Belajar & $25,00 \%$ & $69,44 \%$ & $86,11 \%$ & $61,11 \%$ \\
2 & Hasil Belajar & $5,56 \%$ & $27,78 \%$ & $86,11 \%$ & $80,55 \%$ \\
\hline
\end{tabular}

Berdasarkan tabel 12, ketuntasan aktivitas belajar siswa kelas VIIB mengalami peningkatan sebesar $61,11 \%$ dan hasil belajar sebesar $80,55 \%$. Untuk mengetahui pencapaian pada masing-masing indikator aktivitas belajar dapat dilihat pada tabel di bawah ini.

Tabel 13 Data Peningkatan Indikator Aktivitas belajar siswa kelas VIIB pada kondisi Prasiklus, siklus I dan siklus II

\begin{tabular}{|c|c|c|c|c|c|c|c|c|}
\hline \multirow{2}{*}{$\begin{array}{l}\mathrm{N} \\
\mathrm{o}\end{array}$} & \multirow{2}{*}{ Aktivitas Belajar } & \multicolumn{2}{|c|}{ Prasiklus } & \multicolumn{2}{|c|}{ Siklus I } & \multicolumn{2}{|c|}{ Siklus II } & \multirow{2}{*}{$\begin{array}{c}\text { Pening- } \\
\text { katan (\%) }\end{array}$} \\
\hline & & $\mathrm{Jml}$ & $\%$ & $\mathrm{Jml}$ & $\%$ & $\mathrm{Jml}$ & $\%$ & \\
\hline 1 & Membaca/mempelajari materi & 18 & 50,00 & 32 & 88,89 & 36 & 100,00 & 50,00 \\
\hline 2 & Aktif dalam kelompok presentasi & 9 & 25,00 & 25 & 69,44 & 31 & 86,11 & 61,11 \\
\hline 3 & Berani bertanya & 5 & 13,89 & 10 & 27,78 & 13 & 36,11 & 22,22 \\
\hline 4 & Berani menjawab & 4 & 11,11 & 11 & 30,56 & 23 & 63,89 & 52,78 \\
\hline & \% Ketercapaian & 36 & 25,00 & 78 & 54,17 & 103 & 71,53 & 46,53 \\
\hline
\end{tabular}

peningkatan aktivitas membaca atau mempelajari materi sebesar $50 \%$, aktivitas dalam kelompok $61,11 \%$, berani bertanya $22,22 \%$ dan berani menjawab $52,78 \%$. Persentase ketercapaian indikator aktivitas belajar secara klasikal pada prasiklus sebesar 25\% (Kurang aktif), siklus I sebesar 54,17\% (Aktif) dan siklus II sebesar 71,53\% (Aktif). 72 aktivitas membaca/ mempelajari materi. Siswa cukup aktif membaca pada prasiklus dan aktif pada siklus I dan II. Kelompok yang membaca materi dengan penuh keseriusan/konsentrasi dapat menyelesaikan pertanyaan-pertanyaan pada kartu Siapa-Aku dengan cepat dan benar. Jika dalam kelompok terdapat anggota yang malas 
membaca akan lambat dalam menemukan jawaban. Penggunaan alga Siapa Aku yang dikemas dalam bentuk permainan adu kecepatan dan kebenaran bertujuan untuk menciptakan pembelajaran yang menarik dan menyenangkan dengan melibatkan seluruh siswa aktif dalam pembelajaran. Terlihat jelas dalam kegiatan kelompok saat presentasi hampir semua siswa menunjukkan keaktifannya. Pada aktivitas bertanya masih menunjukkan peningkatan yang paling rendah dibandingkan aktivitas yang lain. Siswa lemah dalam Oral activities dan emotional activities sehingga belum memiliki keberanian dalam menanyakan halhal yang berhubungan dengan materi yang belum dipahami meskipun sudah diberikan reward penambahan nilai. Guru berusaha untuk memberikan motivasi ataupun arahan kepada siswa yang terlihat takut bertanya atau ragu-ragu untuk menjawab pertanyaan. Usaha ini menunjukkan keberhasilan terbukti 19 orang $(52,78 \%)$ sudah berani bertanya dan menjawab pertanyaan. Pada penelitian ini peneliti tidak mengukur kualitas pertanyaan dan jawaban tetapi keberanian siswa dalam bertanyajawab.

Peningkatan aktivitas belajar berpengaruh terhadap pencapaian hasil belajar siswa. Siswa yang aktif dalam kegiatan pembelajaran lebih mudah untuk mengingat soal-soal tersebut dari pada yang tidak aktif. Guru memberikan penekanan pada materi-materi yang akan dimunculkan dan memilih jenis tes yang tepat untuk kondisi siswa kelas VIIB. Setiap jenis tes memiliki kelebihan dan kekurangan. Tes obyektif pilihan ganda sangat membantu dalam pencapaian nilai karena tes ini memang cocok diterapkan untuk siswa dengan kemampuan daya pikir yang rendah dan terbukti dengan usaha yang dilakukan, siswa kelas VIIB menunjukkan peningkatan dalam nilai rata-rata dan ketuntasan belajar.

\section{PENUTUP}

\section{Simpulan}

Penggunaan alga SIAPA - AKU dalam pembelajaran IPS materi keragaman bentuk muka bumi dapat meningkatkan aktivitas dan hasil belajar siswa kelas VIIB SMP Negeri 2 Merbau Mataram. Peningkatan aktivitas belajar siswa dari prasiklus ke siklus I sebesar 44,44\% dan siklus I ke siklus II sebesar 16,67\%. Persentase peningkatan secara keseluruhan sebesar $61,11 \%$. Peningkatan hasil belajar siswa dari prasiklus ke siklus I sebesar 22,22\%, dan siklus I ke siklus II sebesar $58,33 \%$. Secara keseluruhan peningkatan hasil belajar sebesar $\mathbf{8 0 , 5 5 \%}$.

\section{Saran}

Sebagai guru IPS kita harus lebih kreatif dan inovatif dalam melaksanakan proses pembelajaran agar materi pelajaran menjadi lebih mudah dipahami oleh siswa, sehingga proses dan hasil pembelajaran akan lebih berkualitas.

\section{DAFTAR PUSTAKA}

AM. Sardiman, 2011. Interaksi dan Motivasi Belajar mengajar. Jakarta: Rajawali.

Djamarah, Sopah. 2000. Pengaruh Model pembelajaran dan Motivasi Interpretasi Terhadap Hasil Belajar. Jurnal pendidikan dan kebudayaan.

Rohani, Ahmad. 2010. Pengelolaan Pengajaran Sebuah Pengantar menuju Guru Profesional. Jakarta: Rineka Cipta

Sudjana, Nana. 2002. Dasar-Dasar Proses Belajar Mengajar. Bandung : Sinar Baru Algensindo. 
Satya Widya, Vol. 33, No. 1. Juni 2017: 64-74

Sudjana, nana. 2004. CBSA Dalam Proses Belajar Mengajar. Bandung: Sinar Baru.

Sanjaya, Wina. 2009. Penelitian Tindakan Kelas. Jakarta: Prenada Media Group.

Winkel, WS. 1987. Psikologi Pengajaran. Jakarta: PT. Gramedia. 